\title{
Poverty Eradication Dilemma: Understanding Poverty Dynamics in Nebbi District, Uganda
}

\author{
Alfred Lakwo*
}

\begin{abstract}
This paper addresses a current methodological gap in poverty measurement, which stems from acknowledging the multi-dimensionality of poverty, on the one hand, and using an income/consumption measurement of poverty as the norm, on the other. The current income-based measure of poverty presents only part of measuring poverty status as a whole. The consumption basket is wrongly taken by those of economic inclination to wholly represent the entire, even nonmonetary valued, range of poverty. The paper approaches this dilemma using a participatory and community-driven approach where the subjective views of people are used to define and categorize the poor, contrary to the poverty line approach. Such categorization was based on the perceived wellness of life and what made/denied wellness. A survey follows to explore the quantitative scope of poverty. This participatory, qualitative and quantitative mix of method, it is argued, provides for ascertaining organizational accountability in terms of the relevance of programme targeting and outreach as well as performance measurement over time. The method can also be used to deepen current participatory poverty assessments that simply stop at defining and identifying poverty causes, effects and solutions.
\end{abstract}

\section{Résumé}

Ce document porte sur la déficience méthodologique notée actuellement dans la mesure de la pauvreté. Ceci découle, d'une part, du caractère multidimensionnel de la pauvreté, et d'autre part, de l'utilisation comme norme de la mesure de la

* Programme Director, Agency for Accelerated Regional Development, P.O. Box 80, Nebbi, Uganda; Visiting Lecturer, Institute of Ethics \& Development Studies, Uganda Martyrs University, P.O. Box 5498, Kampala, Uganda; e-mail: alakwo@umu.ac.ug; and a doctoral candidate at Radboud University, Nijmegen, The Netherlands. 
pauvreté basée sur revenu/ consommation. La mesure courante de la pauvreté basée sur le revenu ne présente que partiellement l'état de la pauvreté prise globalement. Le panier de la consommation a été considéré par les thèses économiques comme l'élément qui représente tous les aspects de la pauvreté, même ce ceux avec une valeur non-monétaire. Le document parle de ce dilemme en adoptant une approche participative basée sur la communauté où les opinions subjectives des populations servent à définir et à catégoriser les pauvres, contrairement à l'approche basée sur le seuil de la pauvreté. Une telle catégorisation était basée sur la supposée situation de bien-être et ce qui favorise/empêche le bien-être. A cet effet, une étude a été menée pour mesurer la pauvreté de façon quantitative. D'aucuns pensent que cette combinaison d'approches participative, qualitative et quantitative permet de s'assurer du sens de la responsabilité institutionnelle en terme de pertinence du ciblage du programme ainsi que de la vulgarisation et de la mesure de la performance au fil du temps. Cette approche pourrait également aider à approfondir les méthodes participatives de mesure de la pauvreté utilisées en ce moment et qui ne se limitent qu'à définir et à identifier les causes et effets de la pauvreté, et à proposer des solutions.

\section{Introduction}

Poverty debates have been raging for some time. More fundamental has been the conflict on measurement method, which has widened from a narrow view of material deficiency - income and consumption - through to basic needs considered as acceptable human decency to human development (see UNDP 1997: 15). Yet, with the politicization and prescription of poverty from an insiders' viewpoint, new dimensions such as vulnerability and voicelessness are equally given prominence (Kanbur and Squire 1999: 19-23).

However, while poverty is now considered as multi-dimensional in both its causes and effects (World Bank 2000), its measurement has remained static, with the preferred measure being household income/consumption in relation to a set of basic needs weighed along purchasing power parity. Apart from the data sources being questionable, this approach ignores the nowaccepted multi-dimensionality of poverty. This study, therefore, attempts to solve this problem with reference to the dilemma faced by an NGO in terms of its organizational relevance - vision translation into programme targeting and outreach.

The second part of the paper presents the Ugandan poverty measurement dilemma using the Poverty Eradication Action Plan (PEAP), an all-inclusive anti-poverty formula with diverse definitions and policy strategies. The third part presents a meso-level dilemma of how the operationalization of PEAP is not carried out by a focus on poverty at a decentralized local government level. In the fourth part the paper shows how these dilemmas culminate in functional accountability questions for development partners using the example of a non-governmental organization. Finally, in the fifth part, a methodological 
exploration is presented. Herein poverty definition and measurement are anchored on a participatory and community-driven approach.

\section{Poverty? Uganda's dilemma}

Despite relentless efforts to bring about development to 'developing' countries from the 1940s, the development industry recently took a new approach, codenamed the anti-poverty agenda. Thus, poverty reduction has continued to receive increasing political, business and academic attention. In Uganda, the Poverty Eradiation Action Plan (PEAP), as part of the globally driven poverty reduction strategy, was formulated in 1997 (and is revised every two years) as an umbrella under which coordinated actions are to be taken to ensure that Uganda, in line with the Millennium Development Goals (MDGs), reduces poverty levels to less than $28 \%$ by 2014 . In this vein, five pillars are identified as the cardinal grounds for guiding government resource mobilization, allocation and utilization (see Appendix 1). The pillars are: (i) economic management; (ii) production, competitiveness and income; (iii) security, conflict resolution and disaster management; (iv) good governance; and (v) human development (MoFPED 2004: xvi-xxvi). Through the Medium Term Expenditure Framework, Poverty Action Funds are invested by central and local governments, donor communities, the private sector and civil society organizations.

Supported by policies like decentralization, liberalization and privatization of the economy, and many others, over the years, it is noted that Uganda's poverty trends have tremendously reduced, from $56 \%$ in 1992 to $37 \%$ in 2005, although marked geographical variations exist, as is shown in Table 1.

Table 1: Percent distribution of poor households by residence ${ }^{1}$

\begin{tabular}{|c|c|c|c|c|c|c|c|}
\hline & 1992/93 & 1993/94 & $1994 / 95$ & $1995 / 96$ & 1996/97 & $1999 / 2000$ & $2002 / 03$ \\
\hline \multicolumn{8}{|c|}{ Residential distribution } \\
\hline Total & 55.5 & 52.2 & 50.1 & 48.5 & 44.0 & 35.0 & 37.7 \\
\hline Rural & 59.4 & 56.7 & 54.0 & 53.0 & 48.2 & 39.0 & 41.1 \\
\hline Urban & 28.2 & 20.6 & 22.3 & 19.5 & 16.3 & 10.0 & 12.4 \\
\hline \multicolumn{8}{|c|}{ Regional distribution } \\
\hline Northern & 71.3 & 69.2 & 63.5 & 68.0 & 58.8 & 65.0 & 63.6 \\
\hline Eastern & 59.2 & 58.0 & 64.9 & 57.5 & 54.3 & 37.0 & 46.0 \\
\hline Western & 52.8 & 56.0 & 50.4 & 46.7 & 42.0 & 28.0 & 31.4 \\
\hline Central & 45.5 & 35.6 & 30.5 & 30.1 & 27.7 & 20.0 & 22.3 \\
\hline
\end{tabular}

Source: MoFEPD (2001, 2004). 
Table 1 shows a remarkable performance in the fight against poverty. In a decade Uganda achieved an 18\% decline in its 'considered' poverty levels. Not surprisingly, Uganda is regarded by the World Bank, International Monetary Fund and the donor community as an economically successful country. However, many Ugandans, witnessing the controversies in the daily newspapers and advocacy by civil society, would contest such romantic figures. The simple fact is that a $38 \%$ poverty level would mean that only 3 in every 10 people are poor. Yet, poverty analysis points out that the poor are largely rural, female-headed households, are illiterate and are employed in the subsistence agricultural sector, that is, in categories that constitute the majority of the population. Their livelihoods (both as means of living and enjoying their lives) have not changed. On the contrary, these categories are drifting from bad to worse, as the Chronic Poverty Report, 2005 attests.

Beyond the time-honoured conceptual disparities in the definition and measurement of poverty (see Lakwo 2006: 117-20), this controversy points to two distinct issues taken up in the present paper. First, the controversy unearths the unclear definition of poverty, with thus far no agreed-upon definition of poverty (or its antidote development) in Uganda. While government institutions rely on income/consumption status measured by the World Bank's favoured poverty line of US\$1 or 2 per day, a number of civil society organizations prefer the subjective approach that anchors poverty in the perception of the individuals or communities experiencing it. In an attempt to support this view, the first Uganda Participatory Poverty Assessment defined poverty as lack of basic needs and services such as food, clothing, shelter, healthcare, education and powerlessness. The second such assessment added to this list issues of social exclusion, governance, conflict/insecurity, ignorance, unemployment, lack of productive assets and lack of knowledge and awareness (MoFPED 2002: xi).

Surprisingly, although it has been recognized that poverty is multidimensional, hence the widening of the frontier from which to fight it, there has been no clear merger of the objective and subjective approaches (even in PEAP design beyond mere acknowledgement). This omission partly explains why poverty remains a blurred issue that falls somewhere between income/ consumption, powerlessness, social exclusion and lack of knowledge (MoFPED 2002: 11-13).

Arising from this, poverty performance tracking has also lacked focus, despite a monitoring unit set up for it. It has continued to remain rather difficult to measure 'real' accepted poverty status because poverty lies between economics and socio-politics. To date, different monitoring frameworks and indicators are being used (see Table 2 and the PEAP document, MoFPED 2004: 223-39). The indicators reflect the multitudes of 
poverty embedded in income, public services consumption and good governance poverty. But they are disjointed and not aggregated to give one single picture of 'Uganda Poverty Status'. This aggregation failure has led to 'poverty machination' presented by the 'so-called' income/consumption poverty, which fully ignores other facets of poverty. The Ministry of Finance, Planning and Economic Development acknowledged this fact when it noted that, 'the lack of performance indicators and targets for some interventions and the inadequacy of the monitoring and evaluation functions at different levels have aggravated the [poverty tracking] problem further' (MoFPED, n.d.: 172).

Table 2: Some poverty indicators used in Uganda

Perception of poverty

- Lack of adequate food

- Lack of good shelter

- Lack of good clothing

- Inability to afford medical treatment

- Lack of knowledge and information

- Inability to afford secondary education

- No access to clean drinking water

- Inability to access credit facilities

- Lack of cash money for investment

MoFPED (2002: Fig.2.2, p5)

\section{Welfare indicators}

- Take sugar

- Use soap for bathing

- Each child has a blanket

- Has at least a pair of shoes

- Each has at least two sets of clothingMoFPED (2005: 163-5)

In a nutshell, it can be said that in Uganda poverty is everything. Not surprisingly, fighting poverty is a catch-word in the political pursuit of modernization and industrialization even if it has meant forest, schools and other land give-aways to investors. Besides, it is evident that what is considered as Uganda's poverty status is merely half the truth given that it focuses on only one facet of poverty, ignoring what Maxwell (1999: box 1) notes as the multi-dimensionality of poverty:

it [poverty] should best be described as income or consumption poverty, human (under)development, social exclusion, ill-being, (lack of) capability and functioning, vulnerability, livelihood unsustainability, lack of basic needs, and relative deprivation.

From development policy perspectives and especially the demand for accountability it becomes irrelevant to commit a nation and its resources (borrowed funds inclusive) to what cannot be validated. The irrelevance 
emanates from the fact that without a clear definition of what poverty is, there will be a lack of policy focus (or national vision). Hence, the inclination to opt for the World Bank 'one-size-fits-all' income poverty measure without questioning its relevance beyond global policy/technical prescription continues to create more dilemmas for poverty reduction (and attaining the MDGs).

\section{Nebbi district's sketchy solution}

Nebbi district is one of the 80 districts in Uganda. It is located in the northwest of the country and is the gateway to the other six districts in the West Nile region. As a decentralized local authority, Nebbi district is charged with the responsibility of developing its constituency while taking care of central government priorities. Tol this end the district has formulated a three-year development plan that envisions 'wealth and prosperity for all', tied to a mission 'to serve the community through a coordinated delivery of services which focus on national and local priorities and contribute to the improvement in the quality of life of the people in the district'. As such, the district operational goal is 'to improve incomes of the poor, improve the quality of life in the district, and promote good governance, harmony and security' (DPU, 2006: vii). Central in all this organizational positioning is the pursuit to fight poverty among its people.

One then asks: 'what is the poverty to be fought? How much of it exist and where?' In an attempt to answer these questions, in 2002, Community Empowerment for Rural Development (CEFORD) was contracted, with Royal Netherlands Embassy (RNE) budget support, to conduct a Participatory Poverty Assessment. This study was conducted in only four of the nineteen lower local governments. Apart from the methodology being suspect, the study had unclear terms of reference (designed and agreed upon by the District Planning Unit and the contractor) and was conducted without any audit, therefore did not provide for the required feedback. The study lacked analytical rigour, as is manifested in the disjointed definition, manifestation and indicators of poverty (see Appendix 2 for an excerpt from the study).

Consequently, the CEFORD study was not harmonized into a District Poverty Assessment report with a Summary Status/Synthesis Report for Nebbi District that would answer questions such as, "what is poverty, how is it felt (and by whom) and what are its interlocking cause/effect relations, and in sum, how poor/rich are the people of Nebbi district?'

Because the study fell into the same trap as the national participatory poverty assessment, Nebbi district (as in Uganda as a whole) to date can neither present its poverty status beyond the rhetoric of being poor because it is located in northern Uganda, nor can it show and distinguish between its poorest vis-à-vis well-off lower local governments. Likewise, without a clear 
poverty status, the basis upon which the poverty reduction policy should focus is missing.

This shortcoming is exemplified by the 'crude' poverty measure used by the District Planning Unit (a centre for the coordination of the district development processes). While poverty is recognized, in line with the 2002 Participatory Poverty Assessment, as 'the inability to meet basic needs such as food, shelter, clothing, basic health care, basic education, lack of information and inadequate household item as paraffin, salt, and soap' (p12), it is technically operationalized in varied measurement indicators. According to the District Planner these indicators include access to roads, number of schools, number of health units, and the proportion paying the lowest quartile of g-tax (personal communication during a brainstorming meeting held with SNV team). ${ }^{2}$ These measures exclude a number of issues raised in the very definition of poverty.

Seen in this way, one continues to wonder about where the eventual outcomes from investing in the pillars of PEAP will place Ugandans in the poverty spectrum. Inherently, this poverty dilemma manifests in affecting the operations of development actors who cannot aggregate their various inputs into a unitary poverty basket that can show the poverty dynamics in Uganda generally and within the various local governments where they are operational specifically. The Agency For Accelerated Regional Development (AFARD) is one such development actor entrapped in this poverty dilemma.

\section{AFARD: caught in the poverty eradication dilemma}

AFARD, formed in July 2000, is a local professional, not-for-profit and nondenominational non-governmental organization (NGO) currently operating in Nebbi district. ${ }^{3}$ AFARD's formation was motivated for various reasons. First, the West Nile region where it is operational is located in the poorest northern region of Uganda, where 6 in 10 people live below the daily US\$ 1 standard. Second, many development interventions have been 'external to local context' and imposed, leaving behind physical structures and dysfunctional committees but a people hardly changed. Third, 'democratic centralism and machination' under decentralization has reduced people to subjects and not citizens of the state. Finally, the high human resource flight from the region has limited new innovations and enthusiasms to work for self-development.

Thus, AFARD's vision is, 'a prosperous, healthy and informed people of West Nile' and its mission is, 'to contribute to the moulding of a region in which the local people, including those who are marginalized, are able to participate effectively and sustainably and take a lead in the development of the region'. 
To achieve the above, AFARD's main activities are embedded in capacity-building of 'poor' marginalized communities to realize sustainable livelihoods. This is done by engaging in a number of thematic issues/activities, namely: well-being security (where HIV/AIDS prevention and mitigation, safe water and sanitation promotion, and food security are undertaken); income security (with a focus on community microenterprises development), and good governance (under which gender mainstreaming and advocacy with respect to local government development processes are pursued). For details on these activities, see Appendix 3.

While the thematic focus of AFARD appears straightforward, in terms of the above debate, it is still unclear who the poor are or what is the poverty that AFARD is zealously committed in fighting. This dilemma presented a dilemma within the organization as to how to account (for public image, investment justification and winning staff morale) to its stakeholders (donors, government, peer organizations and the beneficiaries). This study, therefore, aimed at resolving this dilemma as well as creating an opening (through adoption or adaptation) for local government to justifiably commit to poverty reduction.

\section{Exploring the poverty frontiers}

The ambiguity surrounding the poverty debate warranted asking (from an accountability perspective) a cardinal question, 'to what extent is AFARD working with "poor" marginalized communities?' To answer this question, three sub-questions were also further asked, namely:

- First, what is poverty? This question solicited the perception of the manifestation of poverty that the people who live in it experience it. It aimed at breaking the World Bank's technocratic US\$1 a day prescription by giving voice to the poor and understanding the inner meaning to poverty so that poverty can be seen holistically.

- Second, why are the people poor? This question aimed at exploring the causes of poverty where AFARD is working. This would provide an indepth understanding of factors that inhibit the people from living the life they aspire to. Answers to this question would therefore provide ways of positioning AFARD's intervention focus in perspective so that what are addressed are root causes and not symptoms/effects of poverty. ${ }^{4}$

- Finally, are AFARD's interventions relevant? The core aspects of this question are, first, to validate whether or not AFARD is working with the 'poor' marginalzed categories it is committed to work with; and, second, to ascertain whether or not AFARD is working with such people in the right areas of their deprivation. 
These questions were asked because, first, existing national quantitative studies are not district-specific but are regional-based. Even if they were, from the discussion above it is apparent they would be describing only half the poverty story. Second, the national participatory poverty assessments have not been conducted in Nebbi in order to draw valid comparisons. Even if this was the case, in the manner they are done the assessments only provide a policy coherence to the PEAP process because the World Bank wants them so, let alone presenting 'window-dressing' views of poverty that are swallowed up in income/consumption measurements. Finally, for AFARD, working in a district with a population having diverse ethnicity and experiences of poverty, answering these questions would provide a basis for attempting to aggregate the existing poverty status among its 'clients'.

\section{Methodological orientation}

Aware of the diversity of poverty studies, this study took a middle route between the qualitative and quantitative approaches. It started with a participatory approach in order to be able to define poverty and categorize the poor; 5 it ended with a quantitative method in order to aggregate poverty and the poor. The draft study report was discussed in a feedback meeting that involved participants from local governments and other civil society organizations.

The findings to the three sub-questions are now presented and their implications for AFARD are analyzed. For each question, a brief statement on the methodology used is also provided. Finally, concluding remarks are provided in view of the way forward for poverty reduction especially at local government levels.

\section{Finding 1a: The meanings of poverty}

To explore the meaning of poverty, half-day group meetings were held. Of the thirty community- based organizations engaged with AFARD in the food security project ${ }^{6}$ fifteen were randomly sampled. These partner communitybased groups were composed of different members (males only, females only, and mixed). They were located in different agro-ecological settings (farming and trade communities), and the members had different demographic characteristics, economic statuses and political and religious affiliations. Thus, the respondents represented a heterogeneous category that reflected as much of the diversity in local communities as possible.

During the group meetings, facilitated by the AFARD team, group members were introduced to the study objective, that is, understanding what poverty is, who are the poor, and why they are poor. This objective was linked to the food security project that was aimed at ameliorating the condi- 
tions of poverty they (as beneficiaries) were living in. This explanation was given by presenting as honestly as possible AFARD's existing dilemma in understanding the above poverty issues. The honesty was meant to stir the group members to help define AFARD's thinking, for, as one participant pointed out, 'we thought you knew it all yet now it is clear that we know it better than you do'.

It was also emphasized that the team would expect honest responses while every viewpoint would be respected. Thus, the discussion that followed, in which room was given to all group members to air out their views so as to avoid leadership, gender, age, physical ability and educational biases, first focused on the definition of poverty.

What came out from all the discussions was that:

- The term poverty is not foreign to the local communities. The local Alur/ Jonam dialects refer to poverty as 'can' while the opposite of poverty, riches/wealth is termed as 'lonyo'.

- Both poverty and riches inhere in human beings, and in terms of the local adage it is said, can mako dhano gwok ungo' (literally, poverty does not live in a dog but in human beings).

- For both poverty and riches to occur, there are labels that best describe them. A person living in poverty or riches is known as 'jacan' or 'jalonyo' respectively.

- The labels are ascribed to a person depending on his/her lifestyle (or often households). This lifestyle is judged by its wellness (what can be known as well-being) and is termed locally as 'kwo pa dhano'. While 'can' means leading a miserable or bad life ('kwo matek, kwo makonye upe'), riches is 'kwo maber', meaning a 'good life'. Those who live in between these two categories are referred to as leading an intermediate life, or 'kwo ma nya ber ber'.

- The wellness of one's life is dynamic. While at one stage a person may be living a bad life at another point s/he may lead a good or intermediate life. This dynamism reflects how people move in and out of poverty and are therefore not always static in a state of a bad life. ${ }^{7}$ The variation, however, comes about because of the different components of life (what makes living good or bad).

- Given the dynamism and its associated components, the wellness of life makes categorizing people in the groups (communities) possible. The people were then categorized as those living a badly-off, intermediate and 
well-off lifestyle. This can then be construed to mean the poor, nearpoor and rich. ${ }^{8}$

- Finally, and interestingly, one does not need to be rich to lead a well-off life nor poor to lead a bad life. While this contradicts the categorization above, it deepens the fact that it is what determines the wellness of life that matters. Cases of rich people living miserably and those who are the poor living with pride were pointed out. For instance, a shopkeeper who had money but did not buy fish for his family on the weekly market day was ridiculed by the so-called poor who had to sell part of their farm produce to at least afford fish.

Along this line of thought, poverty was described as lack of, inability to achieve and isolation from the desired well-being. These deprivations were seen to emanate from individual, household and the broader community capacity and politics. An elderly woman argued that, 'I'm leading a miserable life because at my age, I no longer have the ability to engage in hard work both on-farm or in the market in order to have adequate food from the garden or income to buy whatever I need.' A teenage mother reiterated the fact that, 'at least we are better off because we still have few dependants as compared to what our energies on the farm can produce for us'. Yet, a male youth said, if the government had created for him the job he was qualified for, his family would not be suffering.

Apart from the old woman's concern for food, the remarks of the teenage mother and the male youth still leave a lot of questions. Up to this point it is still unclear what the better-off or suffering (read badly-off life) actually are. But what is clear is that all these three people strive for a life other than that of the badly-off. The issues of a good life are, therefore, addressed below so as to clarify how judgements are made of what makes a badly-off, intermediate and well-off life.

\section{Finding 1b: Components of a good life}

To explore the different aspects of the wellness of life, the group meetings were asked to list what made their life badly-off, intermediate or well-off. A long list was drawn up as members mentioned what to them best described the wellness of their lives.

This list was later clustered according to various well-being categories (some of which are mentioned in the study of Narayan et al. already referred to). Interestingly, in the indicator identification, the people debated and agreed on what the best measure of such wellness would be; for instance (see Table 3 ), the number of countable assets like livestock, radios and amount of money. In addition, reasons for identifying a given variable were also offered. For instance, land was seen as a productive asset to produce food or rent 
part of it out for immediate cash. Livestock was rated for the social status conferred on owners. An elderly woman pointed out that, without cattle either you die an unmarried person or you engage in a non-traditionally accepted marriage. And both situations are a source of shame to the affected person either directly or indirectly. Should a parent fail to marry for their children, she narrated, their family will be disrespected to the point that the man may be denied a position among his clan's mate. Meanwhile, for the boy, he will fail to fit in with his peers because no one would wish to confide in him given that he is not married (simply because married persons consider that they must discuss important matters only with those who are of their own status).

\section{Finding 2: The causes of poverty}

In order to understand why deprivation occurs in the first place and, secondly, how to translate into the different variables and social categorization stated in Table 3, the causes of poverty were discussed and analyzed. Generally, it was pointed that such deprivation was due to:

- Lack of a sizeable and steady income. A majority of the people indicated that their lifestyle was curtailed by a lack of money, which resulted from: (i) over-reliance on subsistence-oriented and indigenous technology-driven agriculture, which in turn has marginally low yields for both food and sales; (ii) their inability to diversify their livelihood activities because they lacked loans with which to start up or build upon their businesses.

- Inadequate knowledge and skills to live a productive and healthy life. A female youth said, 'how would I know what is the value of good food when I'm not schooled?' Another elderly man remarked, 'by what means other than education can I make a successful business?' This means that for any venture to be productive basic education (of whatever nature) was considered important and its shortfall was a setback to leading the desired lifestyle.

- Lack of access to public services. It was noted that although government should have ideally been providing the villages with services that can increase people's productivity, such as extension services, quality healthcare and road networks among others, in most of these (AFARD project) areas, the communities were isolated from getting government services either because of distance to service centres, neglect by government officials or simply being sidelined as unworthy of services. A respondent echoed the fact that, 'political leaders' simply do not hear our needs. Instead, they provide what they deem fit for us without consultation. Sometimes, they even shamelessly want us to contribute funds towards projects we did not need.' Another reiterated the fact that 


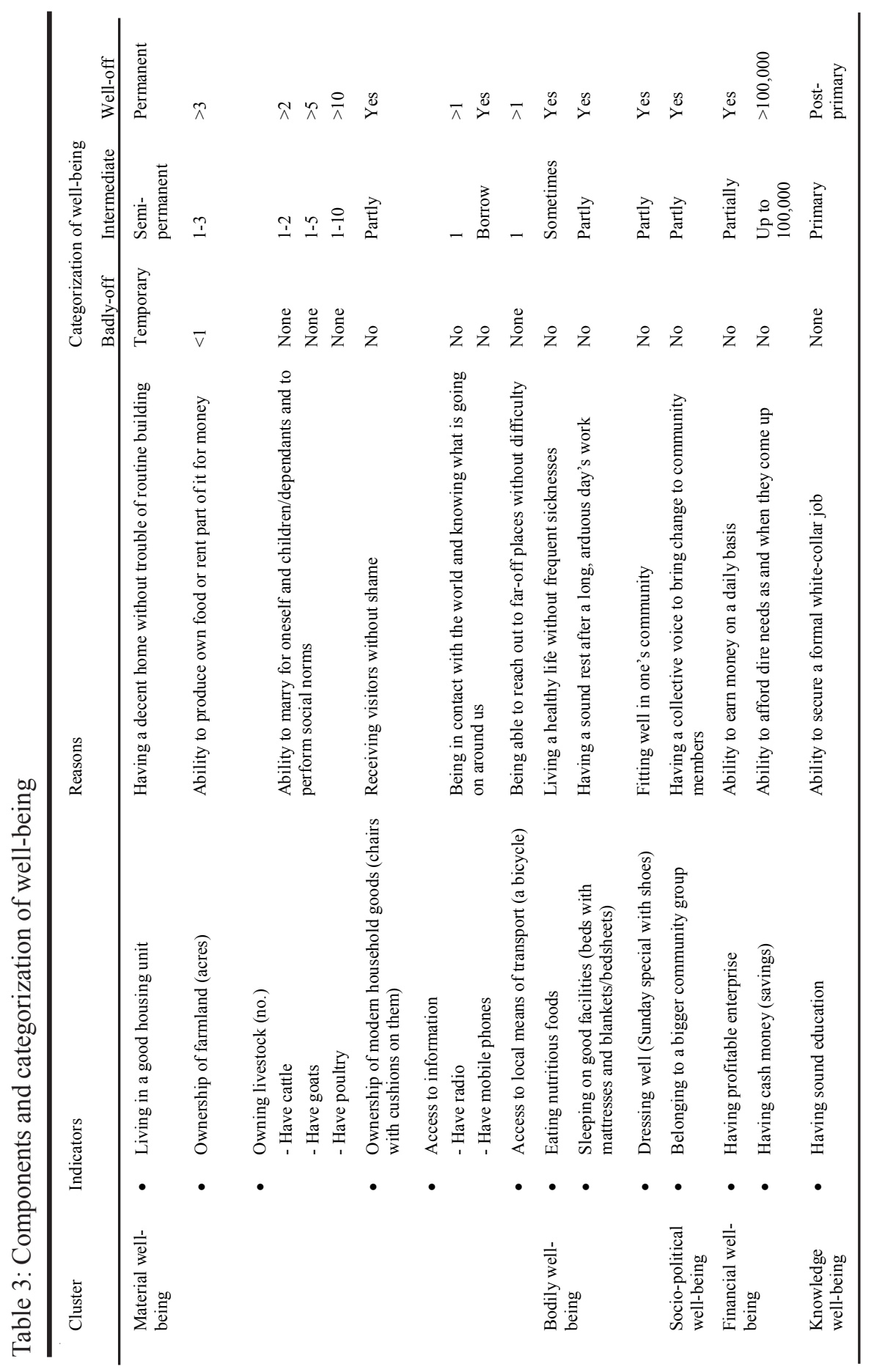


government 'has failed to create jobs for its citizens yet it expects the people to grow rich without telling them how to do so'.

- Cultural discrimination was yet another setback. While the men noted that culture had not put too much burden on them to earn for the everincreasing family sizes, the youths looked at it as a roadblocks that inhibited them from trying new things given that the conservative elders are the ones considered to have a monopoly on wisdom. To women, such views of the youth were elaborated in view of the ownership of assets (including cash) and eating certain food types.

- Changes in the weather also featured as an impediment to a better life. Many people pointed to the fact that current weather conditions had made life very unpredictable. Apart from reducing productivity from people's own land, climate change had forced many households to deplete their savings (food, livestock and even money) in order to continue surviving. As such, many people are changing many facets of their well-being status because they are unable to cope with life.

\section{Finding 3: Aggregating well-being status}

In order to aggregate wellness of life, on the one hand, and social categorization, on the other, it became important to ascertain the extent to which the members of partner groups were living in what well-being status. This entailed undertaking a rapid quantitative household survey. The use of the household as the unit of analysis at this point was based on the fact that despite the heterogeneity of the members, each lived according to a given wellness that is defined by their household status. For instance, all the prioritized indicators, although belonging to individuals, are held for and on behalf of their households.

Therefore, a quantitative household questionnaire that focused at rapidly establishing the status of every household vis-à-vis the indicators of wellness was designed and pre-tested. With the questions' consistency ascertained, the final data collection was conducted among 23 randomly sampled members of the 15 partner groups involved in the group meetings. Two people (the agronomist and animal husbandry experts) collected the data, under my supervision, on dates agreed upon with the group members. However, while the field data collection was ongoing, data entry was being done concurrently and the analysis completed in a timely manner.

\section{Demographic characteristics of respondents}

This study was conducted among community-based organization members with whom AFARD was undertaking a two-year food security promotion 
project. A total of 338 people (with an average household number of 6 people) were interviewed. ${ }^{9}$ This population was composed of $61 \%$ women (because AFARD gives priority to women in its programmes). About $13 \%$ were aged 14-24 years (although the mean age was 39 years), ${ }^{10}$ and $86 \%$ were married ( $57 \%$ women). A total of $16 \%$ had no formal education ( $15 \%$ women compared to about $1 \%$ men), compared to only $14 \%$ with post-primary education (only 3\% women).

\section{Who AFARD is working with}

Basing on the rating criteria set by the groups, it was found that most of the people engaged in the food security programme were those leading the badlyoff lifestyle. Figure 1 shows that those with a badly-off lifestyle accounted for $54 \%$ of the entire group members interviewed, and those in the intermediate lifestyle category made $38 \%$. Compared to the well-off (or the rich), at a negligible $8 \%$, this finding means that the majority of the group members AFARD is working with are the poor.

Figure 1: Well-being status of respondents

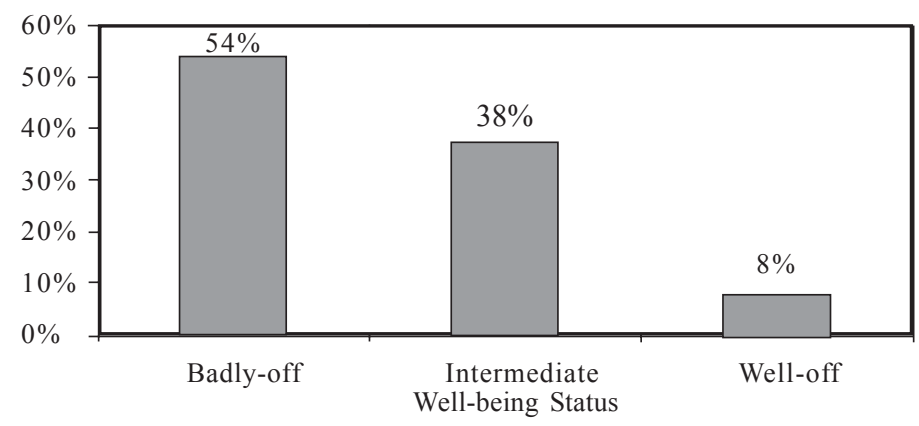

Source: Household data.

\section{Manifestation of deprivation among target groups}

From Figure 2, it is evident that although most of the people are poor (Fig. 1) a majority have a fair status in terms of material well-being (53\%). The core areas of well-being deprivation are socio-political well-being, financial and knowledge well-being and bodily well-being. Of importance is the fact that both those leading badly-off and well-off lifestyles lacked socio-political identification with bigger community groups where they can make their voices heard and secure better services. This affects those with badly-off lifestyles more than those with well-off lifestyles because, first, the latter have the 
ability to afford the required services and, second, they have the potential of 'governance capture', a scenario where they win favours from those in positions of influence (government and NGO officials alike).

Figure 2: Respondents' well-being categories

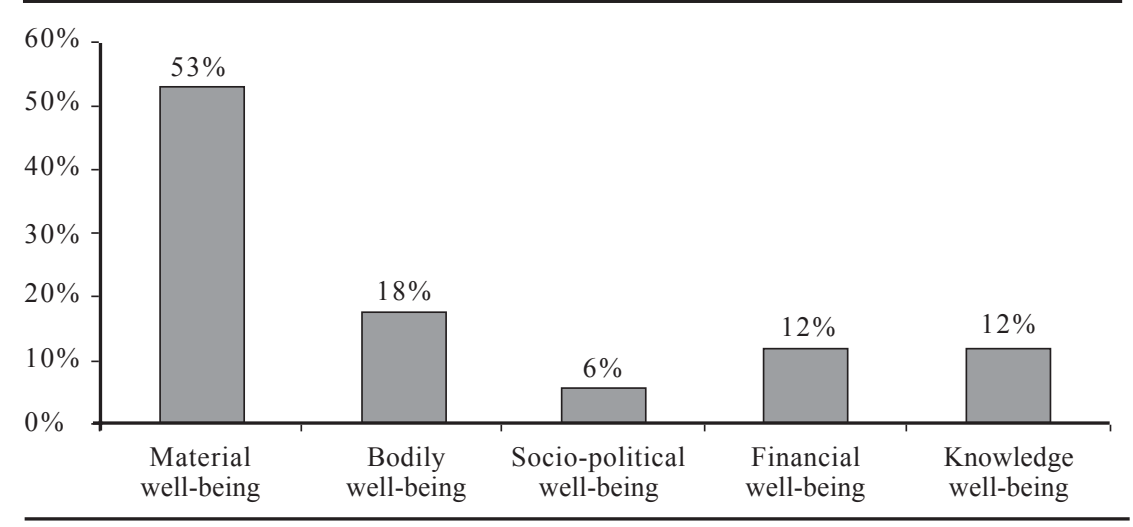

Source: Household data.

While this observation presents the general picture of well-being deprivation, more specifically, as can be seen from Table 4, there are variations in the different facets of deprivation among the different social categories. For instance, those with badly-off lifestyles suffer most (in order of score severity) from social-political (1\%) and knowledge well-being (8\%), while the well-off are deprived of socio-political (2\%) and financial well-being $(8 \%)$. For those at the intermediate category deprivation is in financial $(9 \%)$ and socio-political well-being (14\%).

Table 4: Well-being status by social category (\%)

\begin{tabular}{lcccc}
\hline Categories & Badly-off & Intermediate & Well-off & Total \\
\hline Material well-being & 68 & 34 & 42 & 53 \\
Bodily well-being & 10 & 27 & 27 & 18 \\
Socio-political well-being & 1 & 14 & 2 & 6 \\
Financial well-being & 14 & 9 & 8 & 12 \\
Knowledge well-being & 8 & 15 & 21 & 12 \\
Total & 100 & 100 & 100 & 100 \\
\hline
\end{tabular}

Source: Household data. 


\section{Intervention relevance}

The finding that only $8 \%$ of those engaged in the food security project are 'well-off' illustrates well that indeed AFARD is working with the 'poor' marginalized people in the community. This means that AFARD has the right targeting relevance to ensure that those in dire need are enabled to enjoy their lives.

Further, by looking at the manifestation of deprivation vis-à-vis AFARD's vision and thematic programmes it can be said that AFARD's vision-driven interventions rightly address the areas of core needs. By focusing on income security (financial well-being), health security (bodily well-being) and good governance (socio-political well-being), AFARD is empowering its beneficiaries to directly gain increased status on the various facets of well-being and indirectly to translate these gains into material well being.

However, the exclusion of knowledge well-being (considered as a nonniche focus) is known to have impacted negatively on AFARD's programmes. For instance, in a review of the food security project, it is reported that illiteracy is an impediment to record-keeping, profit calculations and group growth in terms of minute-taking and keeping, among others. It is also known as a constraint on the adoption of rotational leadership as well as taking independent linkage and lobbying roles by group members.

\section{Conclusion}

This study addressed a current gap in the global anti-poverty agenda, which focuses on income/consumption poverty, on the one hand, yet, on the other, it tactically proposes the recognition of a multi-dimensional poverty to which it pays no attention. Taking an organizational accountability focus, the study presented, first, the need to accept that poverty is heterogeneous, hence endogenic to the people who face it. In this way, the orthodoxy of global harmonization in income poverty measurement provides no real change from pursuing the failed dictated development for poverty reduction. For the recognition of a multi-faceted poverty to take root a 'glocal' orientation is imperative because only this will provide a voice for the 'so-called' poor but also allow their aspirations to become part of the anti-poverty policy debate.

Second, the study provides a basis for conducting a relevance test in terms of outreach (category, location and thematic focus). This begs the question of whether or not there is public resource management effectiveness. From a management perspective, it presents a way of asking whether we are reaching out to those in need and addressing their core areas of deprivation. This appears not to be the case in many organizations (government and civil society alike) because resource allocation decisions are based on 'leaders' intuition (and also inherent from their interests). 
For AFARD, this study provides a critical answer to organizational dilemmas. It demonstrated that AFARD is cardinally targeting poor people with badly-off or intermediate well-being status. It also found out that AFARD's vision is relevant in its area of operation. With these positive results, AFARD can justifiably account for its existence and show cause why its resource mobilization drive is necessary. Finally, these findings mean that over time AFARD, together with its beneficiaries, can monitor how far they have moved in enabling the 'poor' marginalized people to realize the lifestyles they aspire to.

Finally, from a methodological perspective, this study presents a new avenue for studying poverty - its scope (or magnitude). Used with longitudinal data, the methodology can also enable poverty trends (transition of scope) and dynamics (transition of variables) analysis. It shed light on the fact that the starting point for any poverty-related policy and study should not be the World Bank-prescribed US\$1 or 2 a day but rather 'what it means to be poor' among the beneficiary groups. The study shows how varied views can be aggregated so that existing multi-dimensional poverty status is known. In this way, the participatory, qualitative and quantitative poverty-research methods can be used to complement each other.

\section{Notes}

1. It should be noted for Table 1 that poverty is measured using an absolute poverty line, which reflects the cost of meeting a minimum of food and nonfood requirements.

2. Note that g-tax was abolished during the 2006 Presidential campaign and would have expected, on the contrary, to be omitted from the poverty measurement.

3. AFARD is also a registered member of the National NGO Forum, Uganda National AIDS Services Organizations (UNASO), Participatory Ecological Landuse and Management - Uganda Chapter (PELUM), West Nile Private Sector Development Promotion Center Ltd, Nebbi District NGO Forum (NDNGOF) and Nebbi AIDS Services Organization Network (NASON).

4. This view does not negate the fact that there are cyclic cause/effect relationships in poverty dynamics. Rather, it appreciates the importance of dealing with the root causes of poverty.

5. Narayan et al. (2000) ably distinguished between wealth (which income poverty measures) and well-being that refers to a good life (pp. 21-43), dimensioning well-being as: material well-being seen as having enough; bodily well-being as being and appearing well; social well-being as ability to care for, bring up, marry and settle children, with self-respect and dignity, peace, harmony and good relations in the family and the community; and security as civil peace, a physically safe and secure environment, personal physical security, lawfulness 
and access to justice, security in old age, confidence in the future, freedom of choice and action.

6. AFARD perceives food security as based on 'Equitable 4As' - 'Availability, Adequacy, Acceptability and Affordability of quality foods, at all times, by all household members regardless of social categorization'. People should always be able to either produce or buy the right food they need.

7. This view also cautions on the chronic poverty focus on intergenerational poverty as well as the sinking deeper into the so-called lowest poverty quartiles. It points to the fact that although one may be taken to be chronically poor, s/ he is in a continuous dynamic within the various facets of the socially accepted badly-off life.

8. However, there was a polarized category of the identified three groups. The poor were divided into two - extremely poor and just poor - and the rich into stinking rich and just rich. I opted not use this subdivision because it was used in only six of the 15 groups.

9. Two things need to be noted here: first, the community-based groups have an average of 25 people and therefore targeting 23 of the 25 members was nearconducting a census; secondly, with 338 responses scored, it represents a $2 \%$ non-response rate from the expected 345 people, which occurred because the identified respondents were engaged in other activities, like attending to the sick or even funerals of relatives.

10. This signifies the low age at marriage that the people engage in, which for those already married was high for women (7\%) compared to men $(3 \%)$.

\section{References}

AFARD, 2006, AFARD Strategic Direction 2007-11: Deepening and widening impacts. Nebbi: AFARD.

Agarwal, B., 1994, A Field of One's Own: Gender and land rights in South Asia. Cambridge: Cambridge University Press.

Agarwal, B., 1997, “Bargaining' and gender relations: Within and beyond the household', Feminist Economics 1(1): 1-51.

Appleton, S., 1995, The Rich are Just Like Us Only Richer: Poverty functions or consumption functions? WPS/95-4. Centre for the Study of African Economies, Oxford (March).

Appleton, S., 1999, Changes in Poverty and Inequality in Uganda, 1992-1997. Kampala: MoFPED.

Appleton, S., 2001, Poverty Dynamics During Growth: The case of Uganda, 19992000. Mimeo. School of Economics, University of Nottingham.

Chronic Poverty Research Centre in Uganda, 2005, Chronic Poverty in Uganda: The policy challenges. Kampala: DRT.

District Planning Unit, 2006, Nebbi District Local Government 3-Year Development Plan for FY 2006/07-2008/08. Nebbi: District Planning Unit (June).

Kanbur, R. and Squire, L., 1999, The Evolution of Thinking About Poverty: Exploring the interaction. Washington, D.C.: The World Bank. 
Lakwo, A., 2006, Microfinance, Rural Livelihoods and Women's Empowerment in Uganda. Leiden: African Studies Centre.

MoFPED, 2001, Uganda Poverty Reduction Strategy Paper Progress Report 2001: Summary of Poverty Status Report. Kampala: MoFPED (8 February).

MoFPED, 2002, Second Participatory Poverty Assessment Report: Deepening the understanding of poverty. Kampala (December).

MoFPED, 2004, Poverty Eradication Action Plan, 2004/05-2007/08. Kampala.

MoFPED, 2005, Poverty Status Report, 2005: Progress in implementing PEAP. Kampala.

MoFPED, n.d., Uganda Poverty Status Report, 2003: Achievements and pointers for the PEAP Revision. Kampala.

Nebbi District Local Government, 2002, Participatory Poverty Assessment for (i) Parombo Sub-county; (ii) Pakwach Town Council; (iii) Nebbi Town Council; and (iv) Zeu Sub-county. CEFORD.

Scott, J., 1998, Seeing Like a State: Why certain schemes to improve the human condition have failed. New Haven: Yale University Press.

UNDP, 1997, The Human Development Report: Human Development to Eradicate Poverty. New York: Oxford University Press

World Bank, 2000, World Development Report 2000/01: Attacking Poverty. New York: Oxford University Press. 


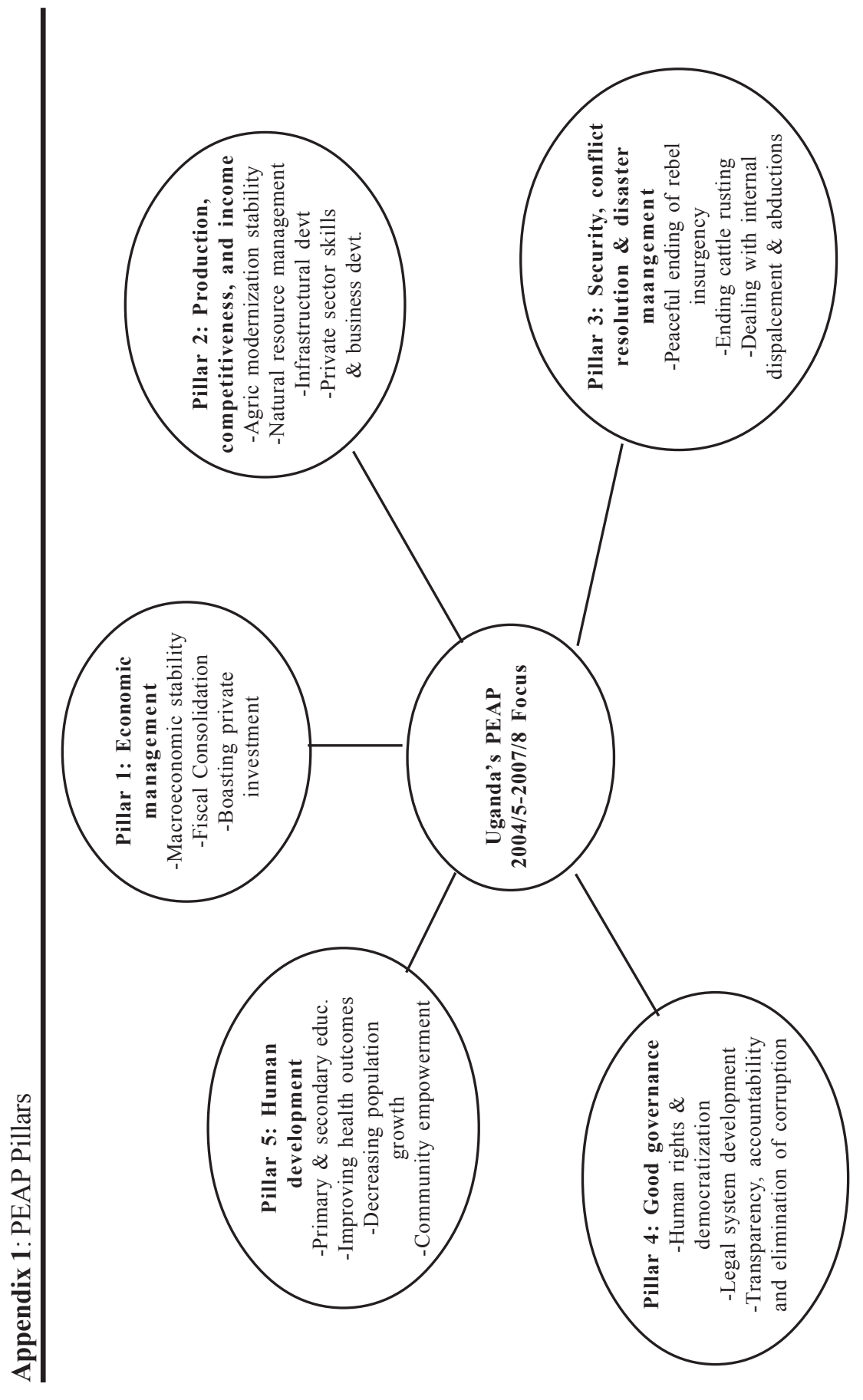


Appendix 2: Perceptions and indicators of poverty

\begin{tabular}{|c|c|c|}
\hline & Area Perceptions of poverty & Indicators \\
\hline & $\begin{array}{l}\text { - Lack of basic necessities like food, } \\
\text { clothes and shelter } \\
\text { - pending sleepless nights from } \\
\text { too many disturbing thoughts } \\
\text { - Body weakness from old age } \\
\text { and/or poor health } \\
\text { - Lack of education, knowledge } \\
\text { and skills } \\
\text { - Missing what one planned to acquire } \\
\text { to acquire }\end{array}$ & $\begin{array}{l}\text { - Body appearance } \\
\text { - Dressing } \\
\text { - Sanitation } \\
\text { - Housing structure } \\
\text { - Access to infrastructure, e.g. } \\
\text { roads, schools and health units }\end{array}$ \\
\hline & $\begin{array}{l}\text { - Limited land for farming } \\
\text { - Inadequate clean water } \\
\text { - Restrictions to fishing ground } \\
\text { - Low/unreliable income } \\
\text { - Poor asset base } \\
\text { - Lack of basic household facilities } \\
\text { - Poor quality of services like water } \\
\text { and health } \\
\text { - Displacement as a result of war } \\
\text { - Food insecurity }\end{array}$ & $\begin{array}{l}\text { - Low level of education } \\
\text { - Rampant theft and idleness } \\
\text { - Risk taking in acquiring resources } \\
\text { across the Nile } \\
\text { - Having one meal a day } \\
\text { - Ill health and constant unhappiness } \\
\text { - Poor shelter } \\
\text { - Lack of land } \\
\text { - Unemployment and odd jobs } \\
\text { - Dependence on friends and relative } \\
\text { - Poor dressing }\end{array}$ \\
\hline & $\begin{array}{l}\text { - Inability to have basic needs at } \\
\text { home and within the community } \\
\text { - Having no support from govern- } \\
\text { ment and remittance from relative } \\
\text { - Inability to do gainful activities } \\
\text { like petty trade }\end{array}$ & $\begin{array}{l}\text { - Poor health } \\
\text { - Poor clothing } \\
\text { - Malnutrition } \\
\text { - Low level of education } \\
\text { - Inaccessibility to services }\end{array}$ \\
\hline U. & $\begin{array}{l}\text { - Lack of basic needs } \\
\text { - Inability to have good livelihood } \\
\text { - Lack of food } \\
\text { - Lack of scholastic materials } \\
\text { - Lack of good clothing and shoes }\end{array}$ & $\begin{array}{l}\text { - Poor dressing } \\
\text { - Ill health } \\
\text { - Illiteracy } \\
\text { - Isolation } \\
\text { - Poor housing and utensils } \\
\text { - Famine } \\
\text { - Lack of social infrastructure, e.g. } \\
\text { schools, health units and roads } \\
\text { - Inadequate community services, } \\
\text { e.g. agricultural extension }\end{array}$ \\
\hline
\end{tabular}

Source: NDLG(2002). 
Appendix 3: AFARD's intervention focus

\section{Theme 1 Community health}

\section{HIV/AIDS prevention and mitigation}

AFARD delved into behaviour change communication in fishing villages (for prevention) and family and communitycentred approach for support to Orphans and Vulnerable Children (OVC) and Person Living with AIDS (for mitigation). Awareness creation, psychosocial support, direct support for OVCs in schools and the enhancement of family and community ability to provide basic services and care are the core activities.

\section{Safe water and sanitation promotion}

In promoting Safe Water and Sanitation AFARD provides access to safe water points and toilet facilities at community points and for vulnerable families who are helpless. It also provides safe sanitation and hygiene education through trained voluntary village health committees. These are followed by a community bye-law formulation, approval, launch and enforcement by local courts.

Theme 2 Income security

\section{Sustainable agriculture enhancement}

AFARD focuses on increasing household food production and purchasing power so that food is available, adequate, affordable and acceptable throughout the year for all people for a healthy life. High-value (market and food) crops and livestock are multiplied for on-lending using a group-based approach. Field-based extension services are routinely provided in conjunction with agri-business and nutrition education.

\section{Community microenterprise development}

To promote activity diversification with prudent business practices and self-funding, AFARD integrates the promotion of group savings and credit schemes with incomegeneration skills improvement. Management training for savings mobilization and credit management are provided to all group members. Entrepreneurship skills training focusing on the selection, planning and management of small businesses are also provided

\section{Theme 3 Community empowerment}

\section{Institutional development}

AFARD mainly works with community-based organizations (CBOs). This ensures cost effectiveness and facilitates a 'do-it-yourself' drive for self-reliant development. To enable groups to be competent enough to operate on their own, a facilitation process that starts with the identification of groups is done. This is followed by a participatory capacity selfassessment where each group identifies its organizational strengths and weaknesses. It is the weaknesses that are used in designing a capacity-building plan with the groups. The groups' capacity-building takes the form of training, retraining, networking and linkages, resource mobilization, and advocacy and lobbying. Through periodic review groups ably chart their growth paths and identify their areas of persistent weaknesses.

\section{Good governance}

The drive to promote gender equality compelled AFARD to undertake to facilitate a process to engender services delivery in lower levels of local government. This initiative focuses at widening political space for, and entitlements of, women by increasing women's participation and voice in decisionmaking in local government by promoting the engagement of women and local government leaders (and technical staffs). The intervention includes skills training in gender-responsive planning and budgeting, participatory gender monitoring and evaluation and advocacy and lobbying skills aided by facilitation of and technical backstopping to women to participate in planning processes and monitoring of budgets. Source: AFARD Strategic Direction 2007-11. 
Appendix 4: Well-being score by lifestyle category (\%)

\begin{tabular}{|c|c|c|c|c|}
\hline Well-being indicators & Badly-off & Intermediate & Well- off & Total \\
\hline Nature of housing & 82 & 15 & 3 & 100 \\
\hline Land size & 56 & 18 & 26 & 100 \\
\hline Have cattle & 85 & 14 & 1 & 100 \\
\hline Have goats & 37 & 56 & 7 & 100 \\
\hline Have poultry & 25 & 59 & 16 & 100 \\
\hline Housewares & 88 & 9 & 4 & 100 \\
\hline Have a radio & 89 & 10 & 1 & 100 \\
\hline Have mobile phones & 95 & 4 & 1 & 100 \\
\hline Have a bicycle & 65 & 34 & 1 & 100 \\
\hline Eat nutritious foods & 17 & 73 & 9 & 100 \\
\hline Have good bedding & 37 & 58 & 5 & 100 \\
\hline Dress well & 35 & 43 & 22 & 100 \\
\hline $\begin{array}{l}\text { Belong to a bigger } \\
\text { community group }\end{array}$ & 5 & 92 & 2 & 100 \\
\hline Have a business & 59 & 29 & 11 & 100 \\
\hline Have cash savings & 72 & 28 & 0 & 100 \\
\hline Have sound education & 16 & 70 & 14 & 100 \\
\hline $\begin{array}{l}\text { Support post-primary } \\
\text { education }\end{array}$ & 55 & 29 & 16 & 100 \\
\hline Total & 54 & 38 & 8 & 100 \\
\hline
\end{tabular}

